J. Dairy Sci. 102:629-639

https://doi.org/10.3168/jds.2018-15330

() 2019, The Authors. Published by FASS Inc. and Elsevier Inc. on behalf of the American Dairy Science Association ${ }^{\circledR}$.

This is an open access article under the CC BY-NC-ND license (http://creativecommons.org/licenses/by-nc-nd/4.0/).

\title{
Association between teat skin colonization and intramammary infection with Staphylococcus aureus and Streptococcus agalactiae in herds with automatic milking systems
}

\author{
Line Svennesen, ${ }^{1 *}$ Søren S. Nielsen, ${ }^{1}$ Yasser S. Mahmmod, ${ }^{1,2}$ † Volker Krömker, ${ }^{3}$ Karl Pedersen, ${ }^{4}$ \\ and IIka C. Klaas ${ }^{1} \ddagger$ \\ ${ }^{1}$ Department of Veterinary and Animal Sciences, Faculty of Health and Medical Sciences, University of Copenhagen, 1870 Frederiksberg C, \\ Denmark \\ ${ }^{2}$ Infectious Diseases, Department of Animal Medicine, Faculty of Veterinary Medicine, Zagazig University, 44511-Zagazig, Sharkia Province, Egypt \\ ${ }^{3}$ Department of Microbiology, University of Applied Sciences and Arts, 30453 Hannover, Germany \\ ${ }^{4}$ National Veterinary Institute, Technical University of Denmark, 2800 Kongens Lyngby, Denmark
}

\section{ABSTRACT}

The objective of this study was to investigate the association between teat skin colonization and intramammary infection (IMI) with Staphylococcus aureus or Streptococcus agalactiae at the quarter level in herds with automatic milking systems. Milk and teat skin samples from 1,142 quarters were collected from 300 cows with somatic cell count $>200,000$ cells $/ \mathrm{mL}$ from 8 herds positive for Strep. agalactiae. All milk and teat skin samples were cultured on calf blood agar and selective media. A subset of samples from 287 quarters was further analyzed using a PCR assay (Mastit4 PCR; DNA Diagnostic A/S, Risskov, Denmark). Bacterial culture detected Staph. aureus in 93 (8.1\%) of the milk samples and $75(6.6 \%)$ of the teat skin samples. Of these, $15(1.3 \%)$ quarters were positive in both the teat skin and milk samples. Streptococcus agalactiae was cultured in $84(7.4 \%)$ of the milk samples and $4(0.35 \%)$ of the teat skin samples. Of these, $3(0.26 \%)$ quarters were positive in both the teat skin and milk samples. The PCR detected Staph. aureus in 29 (10\%) of the milk samples and $45(16 \%)$ of the teat skin samples. Of these, $2(0.7 \%)$ quarters were positive in both the teat skin and milk samples. Streptococcus agalactiae was detected in $40(14 \%)$ of the milk samples and 51 $(18 \%)$ of the teat skin samples. Of these, 16 (5.6\%) quarters were positive in both the teat skin and milk samples. Logistic regression was used to investigate the

Received July 5, 2018.

Accepted September 24, 2018.

*Corresponding author: line.svennesen@sund.ku.dk

$\dagger$ Current address: IRTA, Centre de Recerca en Sanitat Animal (CReSA), Campus de la Universitat Autònoma de Barcelona, 08193-Bellaterra, Barcelona, Spain. 14741 association between teat skin colonization and IMI at the quarter level. Based on bacterial culture results, teat skin colonization with Staph. aureus resulted in 7.8 (95\% confidence interval: $2.9 ; 20.6)$ times higher odds of Staph. aureus IMI, whereas herd was observed as a major confounder. However, results from the PCR analyses did not support this association. Streptococcus agalactiae was isolated from the teat skin with both PCR and bacterial culture, but the number of positive teat skin samples detected by culture was too low to proceed with further analysis. Based on the PCR results, Strep. agalactiae on teat skin resulted in 3.8 (1.4; 10.1) times higher odds of Strep. agalactiae IMI. Our results suggest that Staph. aureus and Strep. agalactiae on teat skin may be a risk factor for IMI with the same pathogens. Focus on proper teat skin hygiene is therefore recommended also in AMS.

Key words: B-streptococci, contagious mastitis, dairy cattle, PCR

\section{INTRODUCTION}

Intramammary infections with Staphylococcus aureus and Streptococcus agalactiae are usually associated with subclinical infections that reduce milk quality and production (Keefe, 2012). Staphylococcus aureus and Strep. agalactiae are traditionally considered contagious mastitis pathogens that transfer from cow to cow during milking [e.g., by contaminated milking equipment and milkers' hands (Keefe, 2012)]. The teat skin might therefore serve as a reservoir of pathogens that enter the udder through the teat canal and cause IMI.

It is generally agreed that Staph. aureus can be isolated from the teat skin and other extramammary body sites (Larsen et al., 2000; Haveri et al., 2008; da Costa et al., 2014), and teat skin colonization with Staph. aureus has subsequently been epidemiologically associ- 
ated with Staph. aureus IMI in heifers and cows (Roberson et al., 1994; da Costa et al., 2014). Furthermore, the same pulsed-field gel electrophoresis types of Staph. aureus have been isolated from both teat skin and milk within herd, cow, or quarter (Haveri et al., 2008; Piccinini et al., 2009; da Costa et al., 2014). To the best of our knowledge, the role of the teat skin as a source of Staph. aureus IMI has not been investigated in herds with automatic milking systems (AMS), where milking hygiene and teat cleaning may differ from conventional milking systems (Hovinen and Pyörälä, 2011). Lactating dairy cows can be milked several times a day in AMS without being in contact with human hands, and up to 60 cows can be milked with the same milking unit (Rodenburg, 2017). These factors are likely to affect teat skin colonization and the transmission of contagious mastitis pathogens.

To our knowledge, the association between Strep. agalactiae on teat skin and in milk has not yet been studied. Streptococcus agalactiae were isolated from teat skin and other areas on cows and in cowsheds by Chodkowski (1949). However, Strep. agalactiae was still considered an obligate intramammary pathogen (Keefe, 1997) until an environmental reservoir was recently suggested by Jørgensen et al. (2016), as Strep. agalactiae were isolated from, for example, water troughs, milking robots, and stalls, and the rectum and vagina of the cows (Jørgensen et al., 2016; Farre et al., 2017; Henriksen et al., 2017).

Although bacterial culture has mostly been used to study the above-mentioned aspects, PCR has generally been used more frequently in recent years, particularly in European countries (Koskinen et al., 2010; Mahmmod et al., 2013a,b; Nyman et al., 2016). The PCR assay may have a higher analytical sensitivity, and the potential to detect a broader range of bacteria simultaneously without additional diagnostic efforts. However, the PCR assay may detect nonviable bacteria (Koskinen et al., 2009), which have no important role in transmission. Nonviable bacteria may be considered as false-positive reactions in this regard, whereas viable bacteria only are detected by bacterial culture. However, nonviable bacteria may also be an expression of past exposure, where the bacteria have been killed by teat disinfectants or other circumstances. As such, bacterial culture may be considered more specific for some interpretations. Therefore, the use of both methods may provide information on slightly different aspects of the pathogens in the udder and the surroundings.

Knowledge of pathogen reservoirs is crucial in the management of Staph. aureus and Strep. agalactiae transmission to prevent IMI. In large dairy herds and herds with AMS, controlling transmission related to milking is fundamental in reducing the number of new infections with contagious mastitis pathogens. The objective of the current study was to investigate the association between colonization of the teat skin and IMI with Staph. aureus or Strep. agalactiae in the same quarter in dairy herds with AMS. The results provide new knowledge to improve strategies for the control of Staph. aureus and Strep. agalactiae in dairy herds.

\section{MATERIALS AND METHODS}

\section{Herds and Animals}

Eight Danish dairy herds were selected for inclusion in this field study by convenience sampling, and were visited once between February and May 2017. The herd-level inclusion criteria were as follows: at least 3 automatic milking units, a positive Strep. agalactiae status, and a willingness from the farmer to participate. The status of Strep. agalactiae was based on the annual screening of bulk tank milk samples (BTMS) in 2016 using the quantitative PCR Mastit4 test (DNA Diagnostic A/S, Risskov, Denmark). To confirm that the herds were still positive for Strep. agalactiae, another 3 BTMS from each herd were tested with Mastit4 in January 2017. The herds were considered positive if at least 2 out of 3 BTMS were positive for Strep. agalactiae with a PCR cycle threshold $(\mathbf{C t}) \leq 32$.

Between 30 and 40 cows with SCC >200,000 cells/ $\mathrm{mL}$ at the last milk recording were randomly selected from each herd using a random number generator in SAS 9.4 (SAS Institute Inc., Cary, NC). Cows that received antimicrobial treatments during the 4 wk before sample collection or that were dried off in the 5 to 33 $\mathrm{d}$ between the last milk recording and sampling were excluded. All functional quarters of the selected cows were sampled. Herd and sample size details are presented in Table 1.

\section{Collection of Milk and Teat Skin Samples}

Cows were restrained in headlocks during sampling. Teats were cleaned with dry paper towels until visually clean, with at least one piece of paper used for each quarter. The teat skin samples were collected using a modified wet-and-dry swab technique (Paduch and Kroemker, 2011). Briefly, a sterile rayon swab (DaklaPack, Glostrup, Denmark) was moistened with 1/4 Ringer's solution (Merck, Darmstadt, Germany) and rotated $360^{\circ}$ around the teat at a distance of $1 \mathrm{~cm}$ from the teat canal orifice. The same procedure was followed using a dry swab and the tips of both swabs were transferred into the same tube containing $2 \mathrm{~mL}$ of $1 / 4$ Ringer's 




solution. Data on Danish Holstein cows suggest that the mean teat diameter is $2.3 \mathrm{~cm}$ (unpublished genetic evaluation data, SEGES P/S, Aarhus, Denmark). We therefore estimated the sampled area of the teat to be $7.2 \mathrm{~cm}^{2}$ based on a swab length of $1 \mathrm{~cm}$.

Teat end hyperkeratosis was scored using a 4-point scale (Mein et al., 2001) immediately after the teat skin samples were collected. The teats were forestripped and milk samples were collected aseptically following the procedures described by the National Mastitis Council (Hogan et al., 1999) as follows: the teat end was disinfected with cotton pads moistened in $70 \%$ ethanol, and 2 to 3 squirts of milk were discarded before 5 to $10 \mathrm{~mL}$ was collected in a sterile tube.

Milk and teat skin samples were stored at $5^{\circ} \mathrm{C}$ before laboratory analysis on the following day.

Teat skin sampling and hyperkeratosis scoring was carried out by the same 3 trained veterinarians. Milk samples were collected by 3 milk quality technicians. A veterinarian and a milk quality technician worked together as a sampling team, and the sampling team and sequence were recorded. Disposable gloves were worn when collecting samples, and these were replaced between teat skin and milk sampling, and between each animal. The sampling time was on average $10 \mathrm{~min} / \mathrm{cow}$ per team.

\section{Laboratory Procedures}

Teat skin samples were acclimatized and vortexed for $20 \mathrm{~s}$ before the swab tips were removed with a pair of sterile tweezers. A whole agar plate was inoculated with $100 \mu \mathrm{L}$ of the swab solution. Milk samples were acclimatized and vortexed for $10 \mathrm{~s}$ on a vortex mixer and $10 \mu \mathrm{L}$ of milk was streaked onto a quadrant of an agar plate using a sterile disposable loop.

All samples were plated on blood agar (5\% sheep blood), chromogenic agar selective for staphylococci (SaSelect, Bio-Rad, Hercules, CA), and modified Edwards medium [Oxoid, Roskilde, Denmark, supplemented with $5 \%$ calf blood and $2 \%$ filtrate of a $\beta$-toxinproducing Staph. aureus prepared as described by Jørgensen et al. (2016)]. Plates were incubated aerobically at $37^{\circ} \mathrm{C}$ and examined for growth at 24 and $48 \mathrm{~h}$.

Colonies of Staph. aureus and Strep. agalactiae were phenotypically identified based on colony morphology and hemolysis on blood agar. Staphylococcus aureus was identified as pink colonies on SaSelect agar, as per the manufacturer's instructions. On the modified Edwards medium, Strep. agalactiae was identified as esculin-negative, blue to colorless colonies with a CAMP (Christie, Atkins, Munch-Petersen) reaction. Colony counts were recorded for each plate. A single colony was sub-cultured from each suspected Staph. 
aureus or Strep. agalactiae colony type on a new blood agar and incubated for $24 \mathrm{~h}$ to be freshly submitted to MALDI-TOF (Bruker Biotyper software system, Microflex LT, Bruker Daltonics GmbH, Bremen, Germany), as previously described (Mahmmod et al., 2018). The identification of Staph. aureus was confirmed with MALDI-TOF, whereas Strep. agalactiae was confirmed with a slide agglutination test for Lancefield group B (PathoDxtra Strep Grouping Kit, Thermo Fisher Scientific, Waltham, MA) or MALDI-TOF. The finding of CNS (also confirmed by MALDI-TOF) on SaSelect agar was registered for both milk and teat skin samples, and "other growth" was registered only for milk samples, including environmental streptococci, Enterococcus, and Aerococcus spp. If more than 2 dominant colony types were present, the agar plate was not considered in the reading for milk samples. For teat skin samples, contamination was not considered due to the contaminated origin of the sample.

Teat skin and milk samples from right rear quarters were further analyzed with the Mastit4 PCR test. A FLOQswab (Copan Italia spa, Brescia, Italy) was immersed in the original samples immediately after streaking for bacterial culture. Swabs were shipped on the same day to the analysis laboratory of DNA Diagnostic A/S for analysis 1 or $2 \mathrm{~d}$ later.

\section{Statistical Analysis}

Two data sets were created: one based on culture and the other on PCR. Information on parity, DIM, and SCC on the most recent milk recording day was extracted from the Danish Cattle Database (SEGES $\mathrm{P} / \mathrm{S}$, Aarhus, Denmark). The time between milking and sampling was calculated based on an estimated sampling time and the time of milking from the AMS. The estimated sampling time was calculated by adding 10 min per cow to the first sampling time in each herd, and using the sampling sequence within each sampling team. Somatic cell count was included as an indicator of infection, and hyperkeratosis has been associated with some pathogens (Guarín et al., 2017), whereas time from milking was hypothesized to affect the risk of contamination from the environment and effect of postmilking teat disinfection.

Culture results were dichotomized, and a milk sample with $\geq 1 \mathrm{cfu} / 10 \mu \mathrm{L}(100 \mathrm{cfu} / \mathrm{mL})$ on either blood agar or the selective agar was considered to be positive. Teat skin samples were considered positive with $\geq 1 \mathrm{cfu} / 100$ $\mu \mathrm{L}(10 \mathrm{cfu} / \mathrm{mL})$. For the PCR test, $\mathrm{Ct}$ values $\leq 37$ were considered positive, as suggested by the manufacturer.

The dichotomous variables of Staph. aureus or Strep. agalactiae in milk (IMI) detected by culture or PCR were used as outcome variables for separate models.
The explanatory variable of primary interest was teat skin colonization with the same pathogen and test as the outcome. Parity, DIM, SCC at last milk recording, time since last milking, hyperkeratosis score, and various other pathogens detected in milk and teat skin samples were all included as categorical variables (Table 2) to adjust for different cow-, milk-, and teat-related effects. The categories were created so the numbers of observations in each category were as close to each other as possible while still being meaningful.

Cross-tabulation of all explanatory variables with the 2 outcome variables was performed for both data sets. A logistic regression model was used to estimate the association between teat skin colonization and IMI with the same mastitis pathogen. All variables were first assessed in univariable models, and those with a $P$-value $<0.20$ from an $F$-test were offered to a multivariable model. The full model was reduced using backward elimination based on Hannan-Quinn information criterion, which was used to assess model fit along with model convergence. Furthermore, the Pearson $\chi^{2}$-statistic was used to determine whether unexplained extra-binomial variation was present. For the culture data, the cow identifier was included as a random effect to control for similarity between quarters nested within cows. Herd could not be included as a random effect due to a lack of convergence. Herd was included as a random effect in the PCR data with only one observation per cow to control for cows nested within herds, using a simple diagonal covariance structure. In random effect models, subject specific odds ratios were reported. The analyses were carried out using the Glimmix procedure in SAS version 9.4 (SAS Institute Inc., Cary, NC).

\section{RESULTS}

\section{Culture Results}

Milk and teat skin samples were cultured from 1,142 quarters from 300 cows. Staphylococcus aureus was detected in $93(8.1 \%)$ of the milk samples and $75(6.6 \%)$ of the teat skin samples. Of these, $15(1.3 \%)$ quarters were positive in both the teat skin and milk samples. Streptococcus agalactiae was detected in 84 (7.4\%) of the milk samples and $4(0.35 \%)$ of the teat skin samples. Of these, $3(0.26 \%)$ quarters were positive in both the teat skin and milk samples, and these 3 quarters were from the same cow. Only one quarter was teat skin positive and milk negative. This was a quarter from a cow where Strep. agalactiae was isolated from milk in 2 other quarters.

The distribution of positive milk samples for Staph. aureus and Strep. agalactiae detected by culture is shown in Table 2. Due to the low number of positive samples 
for Strep. agalactiae in teat skin, logistic regression was only performed for Staph. aureus. Furthermore, Strep. agalactiae on teat skin was not offered the Staph. aureus model as a potential explanatory variable. Results from the univariable statistics are shown in Table 2 , with herd, hyperkeratosis score, DIM, CNS, and other growth in milk offered to the multivariable model along with teat skin colonization with Staph. aureus. In the final multivariable analysis, the odds of Staph. aureus IMI were 7.8 [95\% CI; 2.9-20.6] times higher in a quar-

Table 2. Cross-tabulation of Staphylococcus aureus and Streptococcus agalactiae culture positivity in milk samples from 1,142 quarters and the distribution across different variables and $P$-values from univariable statistics (the overall prevalence and herd prevalence are shown at the quarter level)

\begin{tabular}{|c|c|c|c|c|c|c|c|}
\hline \multirow[b]{2}{*}{ Variable } & \multirow[b]{2}{*}{ Level } & \multirow[b]{2}{*}{$\mathrm{N}$} & \multicolumn{3}{|c|}{ Staph. aureus in milk ${ }^{1}$} & \multicolumn{2}{|c|}{$\begin{array}{l}\text { Strep. agalactiae } \\
\quad \text { in } \text { milk }^{1}\end{array}$} \\
\hline & & & $\begin{array}{l}\text { No. } \\
\text { positive }\end{array}$ & $\begin{array}{c}\% \\
\text { positive }\end{array}$ & $\begin{array}{c}P \text {-value } \\
\text { univariable } \\
\text { statistics }\end{array}$ & $\begin{array}{l}\text { No. } \\
\text { positive }\end{array}$ & $\begin{array}{c}\% \\
\text { positive }\end{array}$ \\
\hline Overall & & 1,142 & 93 & 8.1 & & 84 & 7.4 \\
\hline \multirow{2}{*}{ Staph. aureus on teat $\operatorname{skin}^{1}$} & Negative & 1,067 & 78 & 7.3 & 0.012 & 71 & 6.7 \\
\hline & Positive & 75 & 15 & 20.0 & & 13 & 17.3 \\
\hline \multirow[t]{2}{*}{ Strep. agalactiae on teat skin $^{1}$} & Negative & 1,138 & 93 & 8.2 & $\mathrm{NA}^{2}$ & 81 & 7.1 \\
\hline & Positive & 4 & 0 & 0.0 & & 3 & 75.0 \\
\hline \multirow[t]{8}{*}{ Herd } & $\mathrm{H} 1$ & 111 & 18 & 16.2 & $<0.0001$ & 1 & 0.9 \\
\hline & $\mathrm{H} 2$ & 145 & 4 & 2.8 & & 0 & 0.0 \\
\hline & H3 & 148 & 3 & 2.0 & & 10 & 6.8 \\
\hline & $\mathrm{H} 4$ & 144 & 3 & 2.1 & & 10 & 6.9 \\
\hline & $\mathrm{H} 5$ & 149 & 3 & 2.0 & & 17 & 11.4 \\
\hline & H6 & 154 & 2 & 1.3 & & 3 & 2.0 \\
\hline & $\mathrm{H} 7$ & 141 & 8 & 5.7 & & 29 & 20.6 \\
\hline & H8 & 150 & 52 & 34.7 & & 14 & 9.3 \\
\hline \multirow[t]{4}{*}{ Hyperkeratosis } & 1 (no ring) & 64 & 3 & 4.7 & 0.022 & 3 & 4.7 \\
\hline & 2 (smooth ring) & 777 & 48 & 6.2 & & 43 & 5.5 \\
\hline & 3 (rough ring) & 227 & 27 & 11.9 & & 21 & 9.3 \\
\hline & 4 (very rough) & 74 & 15 & 20.3 & & 17 & 23.0 \\
\hline \multirow[t]{3}{*}{ Parity } & 1 & 221 & 21 & 9.5 & 0.88 & 6 & 2.7 \\
\hline & 2 & 378 & 30 & 8.0 & & 30 & 8.0 \\
\hline & $3+$ & 543 & 42 & 7.7 & & 48 & 8.8 \\
\hline \multirow[t]{3}{*}{ DIM } & $<90$ & 291 & 10 & 3.4 & 0.075 & 10 & 3.4 \\
\hline & 90-199 & 345 & 26 & 7.5 & & 20 & 5.8 \\
\hline & $\geq 200$ & 506 & 57 & 11.3 & & 54 & 10.7 \\
\hline \multirow[t]{3}{*}{$\mathrm{SCC}^{3}(\times 1,000$ cells/mL $)$} & $200-399$ & 467 & 39 & 8.4 & 0.9 & 14 & 3.0 \\
\hline & 400-999 & 383 & 27 & 7.1 & & 44 & 11.5 \\
\hline & $\geq 1,000$ & 292 & 27 & 9.3 & & 26 & 8.9 \\
\hline \multirow[t]{5}{*}{ Time since last milking ${ }^{4}$} & $\pm 0.5 \mathrm{~h}^{5}$ & 87 & 0 & 0.0 & 0.35 & 2 & 2.3 \\
\hline & 0.5 to $2.5 \mathrm{~h}$ & 265 & 16 & 6.0 & & 7 & 2.6 \\
\hline & 2.5 to $5 \mathrm{~h}$ & 264 & 27 & 10.2 & & 9 & 3.4 \\
\hline & 5 to $9 \mathrm{~h}$ & 269 & 26 & 9.7 & & 26 & 9.7 \\
\hline & $\geq 9 \mathrm{~h}$ & 257 & 24 & 9.3 & & 40 & 15.6 \\
\hline \multirow[t]{2}{*}{ CNS teat skin ${ }^{1}$} & Negative & 26 & 4 & 15.4 & 0.29 & 1 & 3.9 \\
\hline & Positive & 1,116 & 89 & 8.0 & & 83 & 7.4 \\
\hline \multirow[t]{2}{*}{$\mathrm{CNS}_{\text {milk}}{ }^{1}$} & Negative & 500 & 47 & 9.4 & 0.043 & 27 & 5.4 \\
\hline & Positive & 642 & 46 & 7.2 & & 57 & 8.9 \\
\hline \multirow[t]{2}{*}{ Staph. aureus in milk ${ }^{1}$} & Negative & 1,049 & NA & NA & NA & 77 & 7.3 \\
\hline & Positive & 93 & NA & NA & & 7 & 7.5 \\
\hline \multirow[t]{2}{*}{ Strep. agalactiae in milk ${ }^{1}$} & Negative & 1,058 & 86 & 8.1 & 0.52 & NA & NA \\
\hline & Positive & 84 & 7 & 8.3 & & NA & NA \\
\hline \multirow[t]{2}{*}{ Other growth in milk ${ }^{6}$} & Negative & 753 & 73 & 9.7 & 0.0003 & 71 & 9.4 \\
\hline & Positive & 389 & 20 & 5.1 & & 13 & 3.3 \\
\hline
\end{tabular}

${ }^{1}$ Culture positive: $\geq 1$ colony on the agar plate, corresponding to $\geq 100 \mathrm{cfu} / \mathrm{mL}$ of milk and $\geq 10 \mathrm{cfu} / \mathrm{mL}$ of teat skin sample.

${ }^{2} \mathrm{NA}=$ not applicable, too few data to do further analysis on Strep. agalactiae and thus no univariable statistics to be shown.

${ }^{3} \mathrm{SCC}$ from last milk recording 5 to $33 \mathrm{~d}$ before sampling.

${ }^{4}$ Time since last milking, calculated based on estimated sampling time and milking time from AMS.

${ }^{5}$ Time category " \pm 0.5 h" merged with " 0.5 to 2.5 h" in univariable statistics due to zero positive Staph. aureus quarters (outcome variable) in time category " \pm 0.5 h."

${ }^{6}$ Growth other than CNS, Staph. aureus, and Strep. agalactiae. 
Table 3. Results from the multivariable logistic regression model of association between Staphylococcus aureus culture positivity in quarter milk and teat skin samples from 1,142 quarters

\begin{tabular}{|c|c|c|c|c|c|c|c|}
\hline Variable & Level & Estimate & $\mathrm{SE}$ & Odds ratio & \multicolumn{2}{|c|}{$95 \% \mathrm{CI}$} & $P$-value \\
\hline \multirow[t]{2}{*}{ Staph. aureus on teat skin } & Negative & 0 & & Referent & & & \\
\hline & Positive & 2.05 & 0.5 & 7.76 & 2.92 & 20.6 & $<0.0001$ \\
\hline \multirow{4}{*}{ Herd $(\mathrm{H})$} & H3 & -3.06 & 0.74 & 0.047 & 0.011 & 0.2 & $<0.0001$ \\
\hline & $\mathrm{H} 4$ & -2.69 & 0.73 & 0.068 & 0.016 & 0.29 & 0.0002 \\
\hline & H5 & -3.1 & 0.75 & 0.045 & 0.01 & 0.2 & $<0.0001$ \\
\hline & H8 & 0.91 & 0.42 & 2.47 & 1.08 & 5.69 & 0.033 \\
\hline \multirow{4}{*}{ Hyperkeratosis } & 1 (no ring) & 0 & & Referent & & & \\
\hline & 2 (smooth ring) & 0.1 & 0.71 & 1.11 & 0.27 & 4.49 & 0.89 \\
\hline & 3 (rough ring) & 0.93 & 0.75 & 2.53 & 0.58 & 11.0 & 0.22 \\
\hline & 4 (very rough) & 2.19 & 0.85 & 8.91 & 1.69 & 46.8 & 0.0099 \\
\hline \multirow[t]{2}{*}{ Other growth in milk } & Negative & 0 & & Referent & & & \\
\hline & Positive & -1.25 & 0.36 & 0.29 & 0.14 & 0.58 & 0.0005 \\
\hline
\end{tabular}

ter where Staph. aureus was isolated from teat skin compared with a quarter with a Staph. aureus-negative teat skin sample (Table 3). The odds also increased with increasing hyperkeratosis score, whereas the presence of other pathogens in the milk had a negative effect on the odds of Staph. aureus IMI. Staphylococcus aureus on teat skin and "other pathogens" in milk were confounded by herd, whereas the unadjusted odds ratio was 3.2 (based on data in Table 2) and the adjusted odds ratio was 7.8 (Table 3 ), and this change was primarily due to the addition of herd to the model.

\section{PCR Results}

Milk and teat skin samples from 287 right rear quarters were analyzed with PCR. Staphylococcus aureus was detected in $29(10 \%)$ of the milk samples and 45 $(16 \%)$ of the teat skin samples. Of these, $2(0.7 \%)$ quarters were positive in both the teat skin and milk samples. Streptococcus agalactiae was detected in 40 (14\%) of the milk samples and $51(18 \%)$ of the teat skin samples. Of these, 16 (5.6\%) quarters were positive in both the teat skin and milk samples.

The range of Ct values for Staph. aureus in samples considered positive was (13-37) in milk and (27-37) in teat skin. For Strep. agalactiae, the Ct ranges were (10-37) and (24-37) in milk and teat skin samples, respectively. Three teat skin samples had Ct values between 37 and 40 for Staph. aureus and were thus above the chosen cut-off.

The distributions of positive milk samples for Staph. aureus and Strep. agalactiae detected by PCR are shown in Table 4 . With only one quarter per cow, the distribution of parity, DIM, and SCC represents the sampled population at cow level. Results from the univariable statistics for Staph. aureus IMI are shown in Table 4. Hyperkeratosis, parity, DIM, and CNS on teat skin met the criteria for inclusion in the multivariable analysis $(P$ $<0.20)$. The explanatory variable of primary interest (Staph. aureus on teat skin), did not meet the criteria, and as a consequence, no multivariable analysis was done on Staph. aureus IMI detected by PCR.

Results from the univariable statistics for Strep. agalactiae IMI are shown in Table 4, with the following variables offered to the multivariable model: Strep. agalactiae on teat skin, hyperkeratosis, parity, SCC, and CNS on teat skin.

In the final multivariable analysis, the odds of Strep. agalactiae IMI were 3.8 (95\% CI; 1.4-10.1) times higher in a quarter that was Strep. agalactiae-positive on teat skin compared with a quarter with a teat skin sample negative for Strep. agalactiae (Table 5). The odds of a quarter having Strep. agalactiae in milk were also higher with increasing parity or when PCR showed the teat skin to be positive for CNS. Hyperkeratosis was confounded by SCC at last milk recording [e.g., the odds ratio for hyperkeratosis score 4 compared with scores 1 and 2 was 2.0 (based on the data in Table 4), whereas it was 3.5 in the multivariable model (Table $5)]$.

\section{DISCUSSION}

To the best of our knowledge, this is the first study to demonstrate that teat skin colonization with Staph. aureus and Strep. agalactiae can be associated with IMI in AMS, where the transmission of bacteria during milking likely differs from the conventional milking system. In AMS milkers' hands are not a source of bacteria, but the hygiene in AMS is challenged due to the standard- 
ized cleaning process of teats before and after milking (Dohmen et al., 2010).

The odds of a quarter having Staph. aureus IMI were higher when teat skin colonization was detected using bacterial culture as the diagnostic method; however, we were not able to demonstrate the same association between teat skin colonization and IMI with Staph. aureus using a PCR test. In contrast, the odds of a quarter having Strep. agalactiae IMI were higher when Strep. agalactiae was detected on teat skin by PCR, yet

Table 4. Cross-tabulation and P-values from univariable statistics of Staphylococcus aureus and Streptococcus agalactiae PCR positivity in milk samples from 287 right rear quarters ${ }^{1}$

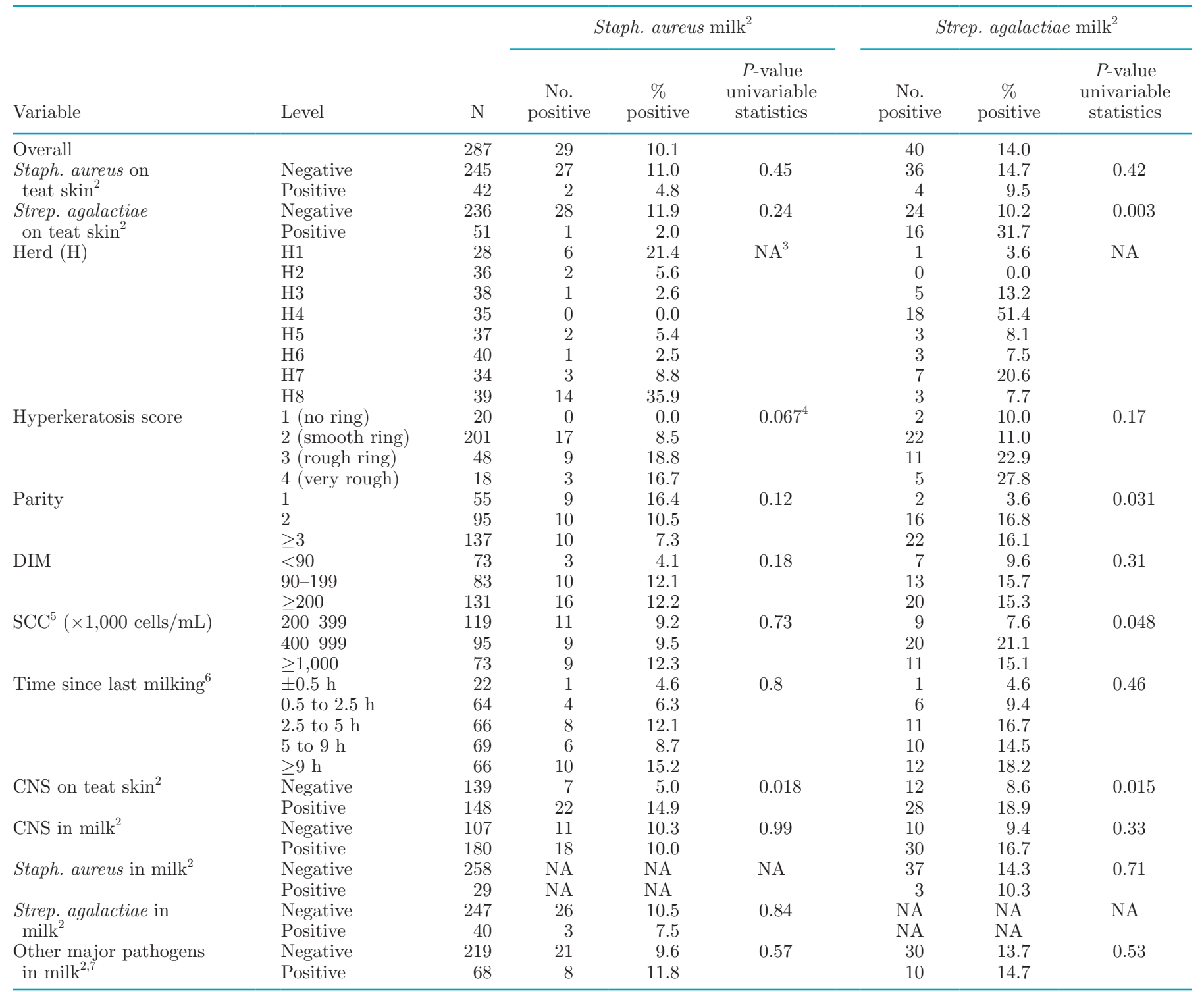

${ }^{1}$ One quarter per cow was selected for PCR; thereby the distribution of parity, DIM and SCC represented the sampled population at the animal level.

${ }^{2} \mathrm{PCR}$ positive: cycle threshold $\leq 37$.

${ }^{3} \mathrm{NA}=$ not applicable.

${ }^{4}$ Hyperkeratosis scores 1 and 2 were merged for univariable statistics due to zero positive Staph. aureus quarters (outcome variable) in score 1. ${ }^{5} \mathrm{SCC}$ from last milk recording 5 to $33 \mathrm{~d}$ before sampling.

${ }^{6}$ Time since last milking, calculated based on estimated sampling time and milking time from AMS.

${ }^{7}$ Including Escherichia coli, Enterococcus spp., and Lactococcus lactis ssp. lactis, Klebsiella spp. (pneumoniae, oxytoca, and variicola), Mycoplasma spp., Streptococcus dysgalactiae, and Streptococcus uberis. 
Table 5. Results from the multivariable logistic regression model of association between Streptococcus agalactiae PCR positivity in quarter milk and teat skin samples from 287 right rear quarters

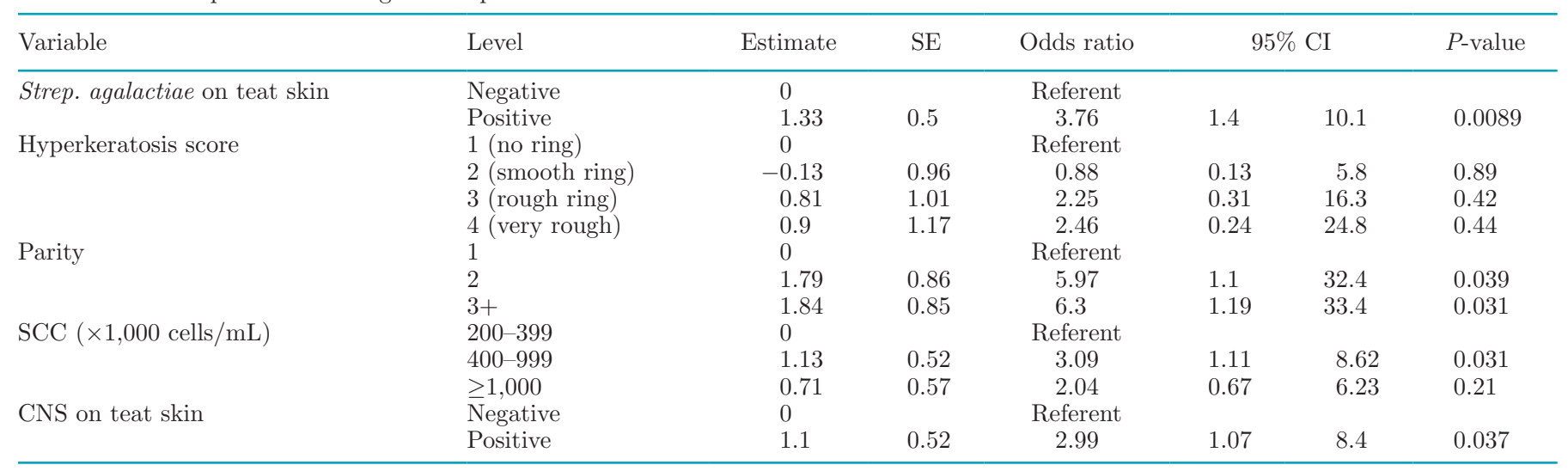

when bacterial culture was used, we only isolated Strep. agalactiae from the teat skin of 2 cows that also had Strep. agalactiae IMI.

As we investigated cows at "high risk" with SCC $>200,000$ cells $/ \mathrm{mL}$ from Strep. agalactiae-positive herds, the recorded prevalence is not comparable to that of the general population.

\section{Staphylococcus aureus}

The association between positive teat skin samples detected by culture and IMI with Staph. aureus in herds with AMS can be interpreted in 2 ways: IMI leads to contaminated teats, or contaminated or colonized teats lead to IMI. Whereas none of the 2 is more obvious than the other, we will discuss the findings in this light. First, a significant number of samples were both PCR and culture positive in teat samples without a simultaneous IMI. Therefore, many of these are considered colonized or contaminated from another source than the milk from the same quarter.

In line with our findings, an association between teat skin colonization and IMI with Staph. aureus was previously reported in conventional milking systems (Haveri et al., 2008; da Costa et al., 2014). da Costa et al. (2014) calculated a relative risk of 4.5 for quarters being diagnosed with Staph. aureus IMI if the teat skin was colonized with Staph. aureus. The study was based on a quarter-level Staph. aureus prevalence of $12 \%$ for milk and $11 \%$ for teat skin, which is slightly higher than the prevalence we found (8.1 and 6.6\%). However, da Costa et al. (2014) selected the cows equally across 3 groups with different Staph. aureus IMI status: known infected, known uninfected, and unknown infection status, whereas our cows were randomly selected among cows with high SCC. Furthermore, da Costa et al. (2014) covered the whole teat with the teat skin swab and included an enrichment step before plating, which likely increased the sensitivity of the bacterial culture and might explain the higher proportion of positive teat skin samples. In a study by Haveri et al. (2008), the proportion of Staph. aureus IMI at the quarter level was 3 to $7 \%$ in the 2 herds included; however, Staph. aureus was isolated from 25 to $68 \%$ of the teat wall and teat orifice samples after including an enrichment step of the nonmilk samples. Pulsed-field gel electrophoresis analysis was also included by Haveri et al. (2008) and da Costa et al. (2014), and the same pulsotypes were found in milk and nonmilk samples.

In contrast, Zadoks et al. (2002) concluded that the teat skin was not an important reservoir of IMI, as they found that different pulsotypes were significantly associated with the site of isolation (milk or teat skin). The contradictory results could be explained by the different approaches; Zadoks et al. (2002) associated pulsotypes of 225 isolates across 43 different herds to the isolation sites, and Haveri et al. (2008) and da Costa et al. (2014) compared pulsotypes across isolation sites at the quarter, cow, and herd level. As discussed by Klaas and Zadoks (2018), the heterogeneity of bacterial strains within and across herds could explain why different studies show different results. Due to limited resources, we did not investigate genotypes in the current study. Therefore, we cannot make sure that the same genotypes were present in milk and teat skin of the same quarter, and this aspect should ideally be investigated further. Nonetheless, it would not be possible to type isolates that are not present, so the origin of bacteria on teats from non-IMI cows would generally have to origin from other cows. The concentrations may not be sufficient to cause an IMI, but this cannot be determined, as we do not know the infectious dose.

In contrast to the bacterial culture results, we were not able to show an association between teat skin and 
milk samples tested by PCR. The PCR data set was a subset of the culture data set, yet the proportion of both milk and teat skin samples positive for Staph. aureus with the PCR test was higher (10 and 16\%) than with bacterial culture (8.1 and 6.6\%). Furthermore, a higher proportion of quarters not detected with IMI had a PCR positive teat skin sample (calculated from Table 2 and Table 4). This could either be due to lower analytical and diagnostic test sensitivity of bacterial culture or lower diagnostic specificity of the PCR test, because the PCR assay may detect viable as well as nonviable and growth-inhibited cells, whereas culture is dependent exclusively on isolation of viable bacterial cells (Koskinen et al., 2009; Mahmmod et al., 2013b). The main challenge in the applied culture protocol was that most teat skin samples (Table 2) contained CNS and the reading was in some cases problematic. This may have led to a low sensitivity of bacterial culture on teat skin samples, which could have been improved by an enrichment step or dilution series of teat skin samples. On the other hand, the PCR test has not been validated for teat skin samples, and the specificity is not known. Furthermore, we do not know how postmilking teat disinfection products might affect teat skin samples and inhibit bacterial growth in bacterial culture without influencing detection using the PCR method.

Like the studies of Haveri et al. (2008) and da Costa et al. (2014), our study is cross-sectional in nature, thus no directionality can be assessed. It is therefore possible that the association is related to contamination of the teat skin by milk containing Staph. aureus. That could also be an explanation of the contradictory results from culture and PCR, if the concentration and viability of Staph. aureus possible to detect by bacterial culture is only sufficient if it originates from milk of the same cow or quarter, whereas what is detected by PCR is also nonviable or low concentrations of Staph. aureus obtained from the environment, milking equipment, and other cows.

\section{Streptococcus agalactiae}

We isolated viable Strep. agalactiae from the teat skin of 2 dairy cows with subclinical mastitis, milked in AMS. To our knowledge, this is the first time Strep. agalactiae have been isolated from teat skin since the reporting by Chodkowski (1949). This result is in line with findings from several other studies conducted in recent years, which state that Strep. agalactiae is able to survive in the environment and can be isolated from extramammary body sites (Jørgensen et al., 2016; Farre et al., 2017; Henriksen et al., 2017). However, calculat- ing an association between teat skin colonization and IMI was not possible due to the low number of positive teat skin samples $(\mathrm{n}=4)$. We therefore cannot exclude that there may be an association when investigating a population with a higher prevalence of Strep. agalactiae. The prevalence reported by Chodkowski (1949) was $38 \%$, and the much lower prevalence $(0.35 \%)$ found in our study may indicate that Strep. agalactiae is not very likely to colonize teat skin. The culture methods differed as Chodkowski (1949) used sterile milk for an enrichment step before plating, likely increasing the sensitivity of bacterial culture compared with our method. Furthermore, the population prevalence could have been much higher in 1949 compared with now. It is, however, more likely that the few quarters we detected as positive on teat skin were contaminated by milk of the same quarter also Strep. agalactiae culture positive.

In contrast to the culture results, an association between Strep. agalactiae on teat skin and in milk was observed using PCR, suggesting that teat skin should be considered as a reservoir for Strep. agalactiae. In addition, Strep. agalactiae was detected using PCR on the teat skin of quarters without IMI (Table 4), which is comparable to observations of Staph. aureus (Haveri et al., 2008; Piccinini et al., 2009; da Costa et al., 2014). A positive result for Strep. agalactiae or Staph. aureus using the PCR assay on nonaseptically collected milk samples could therefore represent contamination from the teat skin instead of a true IMI, thus potentially leading to an incorrect diagnosis (Piccinini et al., 2009; da Costa et al., 2014).

Furthermore, the proportion of Strep. agalactiaepositive teat skin samples detected by PCR (18\%) was considerably larger than when bacterial culture was used $(0.35 \%)$, indicating a higher test sensitivity or lower test specificity of the PCR test compared with bacterial culture, with the same arguments as mentioned for Staph. aureus. Likewise, the prevalence of Strep. agalactiae IMI was higher with PCR (14\%) compared with bacterial culture $(7.4 \%)$. Polymerase chain reaction has previously been reported as more sensitive than bacterial culture in relation to the detection of Strep. agalactiae IMI (Mahmmod et al., 2013b). As for Staph. aureus, the PCR test detecting lower concentrations of bacteria and probably nonviable bacteria on teat skin may likely be the explanation. With regard to the cross-sectional study design, we cannot make sure that teat skin colonization caused the IMI, but it appears that Strep. agalactiae and Staph. aureus in some stage of viability and some level of concentration are circulating in the milking system or surrounding barn environment, making it possible to detect the bacteria 
on the teat skin, especially with PCR. This may be a method of transmission and hygiene, including dirty teats before milking and bad coverage of postmilking teat disinfectant, has previously been associated with udder health in AMS (Dohmen et al., 2010). Therefore, we suggest that reduction of transmission may occur if (1) teats are cleaned before milking, (2) postmilking teat disinfectant is applied with good coverage after milking, and (3) clusters are cleaned between each cow.

\section{CONCLUSIONS}

Our bacterial culture findings showed that teat skin colonization with Staph. aureus resulted in a 7.8 (2.9; 20.6) times higher odds of Staph. aureus IMI in cows with SCC > 200,000 cells/mL in herds with AMS and a history of bulk milk positive for Strep. agalactiae. In contrast, results from a PCR assay on a subset of samples did not support this association, but Staph. aureus was detected in teat skin and milk with both PCR and bacterial culture. Streptococcus agalactiae was also detected in teat skin samples with both PCR and bacterial culture, yet the number of positive teat skin samples detected by culture was too low to carry out further analysis on the association between teat skin colonization and IMI. Results from the PCR assay showed that quarters with Strep. agalactiae on teat skin had a $3.8(1.4 ; 10.1)$ times higher odds of Strep. agalactiae IMI. We conclude that the presence of Staph. aureus and Strep. agalactiae on teat skin may be a risk factor for IMI with the same pathogens and focus on teat skin hygiene is still recommendable; however, no causal relation can be established.

\section{ACKNOWLEDGMENTS}

We acknowledge our masters students Nanna Krogh Skjølstrup and Louise Råkjær Mathiasen (University of Copenhagen) for their great effort during sampling and laboratory analysis. The authors thank the participating dairy herds and DNA Diagnostic A/S, who provided the swabs for PCR analysis and carried out the PCR test. This research was funded by the Danish Milk Levy Fund (Aarhus, Denmark).

\section{REFERENCES}

Chodkowski, A. 1949. The distribution of Str. agalactiae outside the bovine udder and its survival. J. Comp. Pathol. Ther. 59:275-283. https://doi.org/10.1016/S0368-1742(49)80025-7.

da Costa, L. B., P. J. Rajala-Schultz,, A. Hoet, K. S. Seo, K. Fogt, and B. S. Moon. 2014. Genetic relatedness and virulence factors of bovine Staphylococcus aureus isolated from teat skin and milk. J. Dairy Sci. 97:6907-6916. https://doi.org/10.3168/jds.2014-7972.
Dohmen, W., F. Neijenhuis, and H. Hogeveen. 2010. Relationship between udder health and hygiene on farms with an automatic milking system. J. Dairy Sci. 93:4019-4033. https://doi.org/10.3168/ jds.2009-3028.

Farre, M., I. C. Klaas, and U. B. S. Sørensen. 2017. Transmission of Group B Streptococci between Herd Employees and Dairy Cows. Pages 98-99 in Natl. Mastitis Counc. Ann. Mtg. Proc., Tucson, AZ. Natl. Mastitis Counc., Inc., Madison, WI.

Guarín, J. F., C. Baumberger, and P. L. Ruegg. 2017. Anatomical characteristics of teats and premilking bacterial counts of teat skin swabs of primiparous cows exposed to different types of bedding. J. Dairy Sci. 100:1436-1444. https://doi.org/10.3168/jds.2016-11514.

Haveri, M., M. Hovinen, A. Roslof, and S. Pyorala. 2008. Molecular types and genetic profiles of Staphylococcus aureus strains isolated from bovine intramammary infections and extramammary sites. J. Clin. Microbiol. 46:3728-3735. https://doi.org/10.1128/JCM .00769-08.

Henriksen, S. L., T. W. Bennedsgaard, and I. C. Klaas. 2017. Detection of Reservoirs of Streptococcus agalactiae in Automatic Milking Systems. Pages 105-106 in Natl. Mastitis Counc. Ann. Mtg. Proc., Tucson, AZ. Natl. Mastitis Counc., Inc., Madison, WI.

Hogan, J. S., R. N. González, R. J. Harmon, S. C. Nickerson, S. P. Oliver, J. V. Pankey, and K. L. Smith. 1999. Laboratory Handbook on Bovine Mastitis. National Mastitis Council, Madison, WI

Hovinen, M., and S. Pyörälä. 2011. Invited review: Udder health of dairy cows in automatic milking. J. Dairy Sci. 94:547-562. https:/ /doi.org/10.3168/jds.2010-3556.

Jørgensen, H. J., A. B. Nordstoga, S. Sviland, R. N. Zadoks, L. Sølverød, B. Kvitle, and T. Mørk. 2016. Streptococcus agalactiae in the environment of bovine dairy herds - Rewriting the textbooks? Vet. Microbiol. 184:64-72. https://doi.org/10.1016/j.vetmic.2015 .12.014.

Keefe, G. P. 1997. Streptococcus agalactiae mastitis: A review. Can. Vet. J. 38:429-437.

Keefe, G. P. 2012. Update on control of Staphylococcus aureus and Streptococcus agalactiae for management of mastitis. Vet. Clin. North Am. Food Anim. Pract. 28:203-216. https://doi.org/10 $.1016 /$ j.cvfa.2012.03.010.

Klaas, I. C., and R. N. Zadoks. 2018. An update on environmental mastitis: Challenging perceptions. Transbound. Emerg. Dis. 65(Suppl. 1):166-185. https://doi.org/10.1111/tbed.12704.

Koskinen, M. T., J. Holopainen, S. Pyörälä, P. Bredbacka, A. Pitkälä, H. W. Barkema, R. Bexiga, J. Roberson, L. Sølverød, R. Piccinini, D. Kelton, H. Lehmusto, S. Niskala, and L. Salmikivi. 2009. Analytical specificity and sensitivity of a real-time polymerase chain reaction assay for identification of bovine mastitis pathogens. J. Dairy Sci. 92:952-959. https://doi.org/10.3168/jds.2008-1549.

Koskinen, M. T., G. J. Wellenberg, O. C. Sampimon, J. Holopainen, A. Rothkamp, L. Salmikivi, W. A. van Haeringen, T. J. G. M. Lam, and S. Pyorala. 2010. Field comparison of real-time polymerase chain reaction and bacterial culture for identification of bovine mastitis bacteria. J. Dairy Sci. 93:5707-5715. https://doi .org/10.3168/jds.2010-3167.

Larsen, H. D., K. H. Sloth, C. Elsberg, C. Enevoldsen, L. H. Pedersen, N. H. R. Eriksen, F. M. Aarestrup, and N. E. Jensen. 2000. The dynamics of Staphylococcus aureus intramammary infection in nine Danish dairy herds. Vet. Microbiol. 71:89-101. https://doi.org/10 .1016/S0378-1135(99)00161-3.

Mahmmod, Y. S., I. C. Klaas, L. Svennesen, K. Pedersen, and H. Ingmer. 2018. Communications of Staphylococcus aureus and non-aureus Staphylococcus species from bovine intramammary infections and teat apex colonization. J. Dairy Sci. 101:7322-7333. https:// doi.org/10.3168/jds.2017-14311.

Mahmmod, Y. S., N. Toft, J. Katholm, C. Gronbaek, and I. C. Klaas. 2013a. Estimation of test characteristics of real-time PCR and bacterial culture for diagnosis of subclinical intramammary infections with Streptococcus agalactiae in Danish dairy cattle in 2012 using latent class analysis. Prev. Vet. Med. 109:264-270. https:// doi.org/10.1016/j.prevetmed.2012.10.018. 
Mahmmod, Y. S., N. Toft, J. Katholm, C. Gronbaek, and I. C. Klaas. 2013b. Bayesian estimation of test characteristics of real-time PCR, bacteriological culture and California mastitis test for diagnosis of intramammary infections with Staphylococcus aureus in dairy cattle at routine milk recordings. Prev. Vet. Med. 112:309317. https://doi.org/10.1016/j.prevetmed.2013.07.021.

Mein, G. A., F. Neijenhuis, W. F. Morgan, D. J. Reinemann, J. E. Hillerton, J. R. Baines, I. Ohnstad, M. D. Rasmussen, L. Timms, J. S. Britt, R. Farnsworth, N. Cook, and T. Hemling. 2001. Evaluation of bovine teat condition in commercial dairy herds: 1 . Non-infectious factors. Pages 347-351 in 2nd Int. Symp. Mastit. Milk Qual. Proc., Vancouver, Canada. Natl. Mastitis Counc., Inc., Madison, WI.

Nyman, A.-K., K. Persson Waller, U. Emanuelson, and J. Frössling. 2016. Sensitivity and specificity of PCR analysis and bacteriological culture of milk samples for identification of intramammary infections in dairy cows using latent class analysis. Prev. Vet. Med. 135:123-131. https://doi.org/10.1016/j.prevetmed.2016.11.009.

Paduch, J.-H., and V. Kroemker. 2011. Colonization of the teat skin and the teat canal by mastitis pathogens in dairy cattle. Tierarztl. Prax. Ausg. G Grosstiere. Nutztiere. 39:71-76.
Piccinini, R., L. Cesaris, V. Daprà, V. Borromeo, C. Picozzi, C. Secchi, and A. Zecconi. 2009. The role of teat skin contamination in the epidemiology of Staphylococcus aureus intramammary infections. J. Dairy Res. 76:36. https://doi.org/10.1017/S0022029908003671.

Roberson, J. R., L. K. Fox, D. D. Hancock, J. M. Gay, and T. E. Besser. 1994. Ecology of Staphylococcus aureus isolated from various sites on dairy farms. J. Dairy Sci. 77:3354-3364. https://doi .org/10.3168/jds.S0022-0302(94)77277-5.

Rodenburg, J. 2017. Robotic milking: Technology, farm design, and effects on work flow. J. Dairy Sci. https://doi.org/10.3168/jds.2016 $-11715$.

Zadoks, R. N., W. B. van Leeuwen, D. Kreft, L. K. Fox, H. W. Barkema, Y. H. Schukken, and A. van Belkum. 2002. Comparison of Staphylococcus aureus isolates from bovine and human skin, milking equipment, and bovine milk by phage typing, pulsed-field gel electrophoresis, and binary typing. J. Clin. Microbiol. 40:38943902. https://doi.org/10.1128/JCM.40.11.3894-3902.2002. 